Brit. Heart F., 1965, 29, 950.

\title{
Papillary "Tumours" of the Left Ventricle
}

\author{
DONALD HEATH AND IAN MCKIM THOMPSON
}

\author{
From the Department of Pathology, University of Birmingham
}

We report here a unique case of intraventricular polyps of the left ventricle, which appear on gross and histological examination to be identical with papillary tumours of the heart valves. The case is of unusual interest in that the results of histochemical studies are consistent with the view of Koechlin (1908), subsequently elaborated by Pomerance (1961), that such "papillary tumours" are not neoplasms or hamartomas but may be giant Lambl's excrescences.

\section{Case Report}

A woman of 22 years developed severe palpitations during her first pregnancy and was found to have mitral stenosis. She gave birth to a premature child which survived. Three years later she became progressively dyspnœic and had two hæmoptyses. She was admitted to hospital at the age of 26 years for investigation. On examination she had cardiomegaly with a diastolic murmur at the apex conducted into the axilla. Fluoroscopy revealed enlargement of the right ventricular outflow tract and of the left atrium which expanded during ventricular systole indicating mitral incompetence. Cardiac catheterization showed a pulmonary arterial pressure of $63 / 39 \mathrm{~mm} . \mathrm{Hg}$ and a wedge pressure of $30 \mathrm{~mm}$. $\mathrm{Hg}$ at rest. The cardiac output was $5.81 . / \mathrm{min}$. The electrocardiogram showed right bundle-branch block. Two years later she had further hæmoptyses and mitral valvotomy was performed successfully. Aschoff nodes were found in the amputated left atrial appendage. At the age of 31 years she required further bed-rest for dyspnœa and hæmoptysis in the third month of her second pregnancy. A second cardiac catheterization revealed a pulmonary arterial pressure of $70 / 36 \mathrm{~mm} . \mathrm{Hg}$, rising to $132 / 52 \mathrm{~mm} . \mathrm{Hg}$ on exercise. Her cardiac output was $6 \cdot 11 . / \mathrm{min}$. at rest. At the $31 \mathrm{st}$ week of pregnancy she was readmitted with pulmonary infarction. In July 1966 at the age of 39 years she was readmitted to hospital in congestive cardiac failure with dyspncea on exertion and recurrent hæmoptyses. Emergency mitral valvotomy was performed but she developed cardiac arrest and died.
Necropsy Findings. The enlarged heart weighed $690 \mathrm{~g}$. and showed features consistent with pulmonary arterial hypertension. These were dilatation of the right atrium and ventricle, right ventricular hypertrophy $(6 \mathrm{~mm}$.), and dilatation and atheroma of the major pulmonary arteries. The basis for the pulmonary hypertension was mitral stenosis due to chronic rheumatic heart disease. The mitral valve cusps were thickened and fibrotic with nodular calcification; there was fibrosis of the short thick chordæ tendineæ and of the papillary muscles. The left atrium was greatly dilated and there was a calcified plaque, $2 \mathrm{~cm}$. in diameter, situated $2 \mathrm{~cm}$. above the mitral valve ring. The left ventricle contained multiple papilliferous polyps (Fig. 1) which looked like sea-anemones studded over the endocardial surface of the ventricular walls. These masses were grey in colour and mucinous in consistency. Some were minute but one was $2 \mathrm{~cm}$. in diameter. They were mainly closely applied to the columnæ carneæ.

Histological Examination. This confirmed that the masses were highly papilliferous (Fig. 2). Each papilla was composed of a central core, a surrounding sheath, and a covering of endothelial cells, most of which were flattened but some of which were plump and projected from the surface (Fig. 3). The acellular core consisted of granular eosinophilic material with flat cells arranged around its periphery in some instances. The surrounding sheath consisted of a loose basophilic material in which were scattered spindle-shaped cells with vesiculate nuclei which appeared to be fibroblasts. The staining reactions of the core and sheath are shown in the Table. In some of the sheaths of the papillæ there were thin-walled blood vessels. Material taking up stains for fibrin was closely applied as rings around the cores of some of the papillæ (Fig. 4). The material in the core which took up the stain for elastin was punctate rather than fibrillar (Fig. 5 and 6). In some papillæ it showed lamination being arranged in rings (Fig. 5 and 6). The metachromasia of the sheaths on staining with toluidine blue (Fig. 7) was prevented by previous treat950 


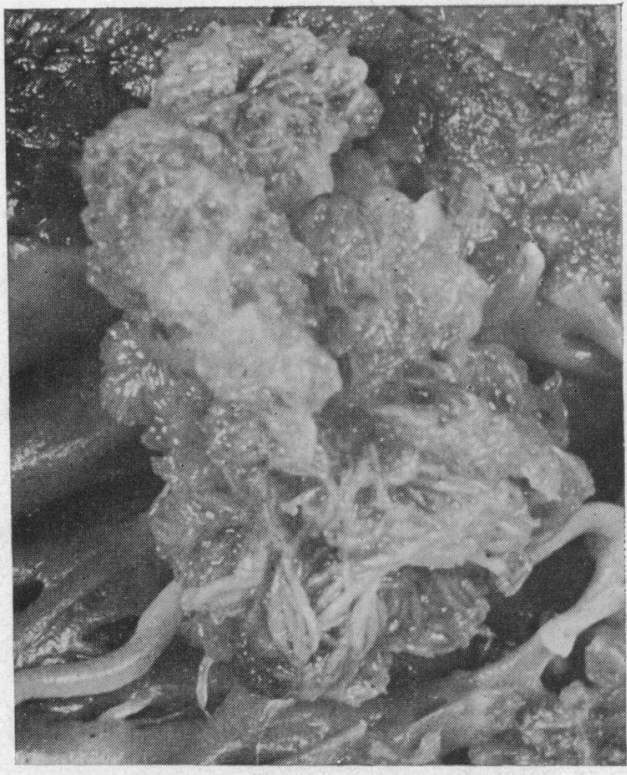

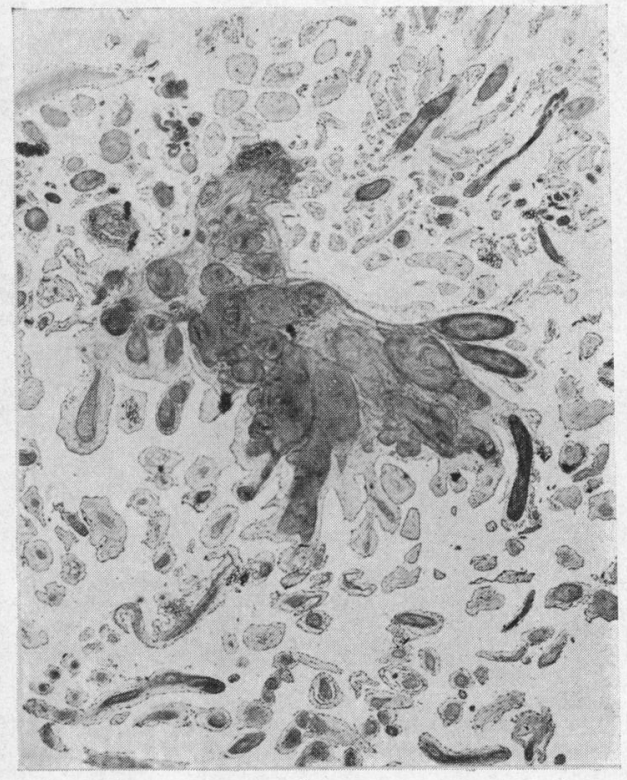

FIG. 1.-The largest of the papillary lesions on the endocardial surface of the left ventricle. Individual papillæ can be seen on the surface of the mucinous mass. $(\times 4$.)

FIG. 2.-General view showing the pedicle and the highly papilliferous arrangement. (Hæmatoxylin and van Gieson. $\times 24$.)
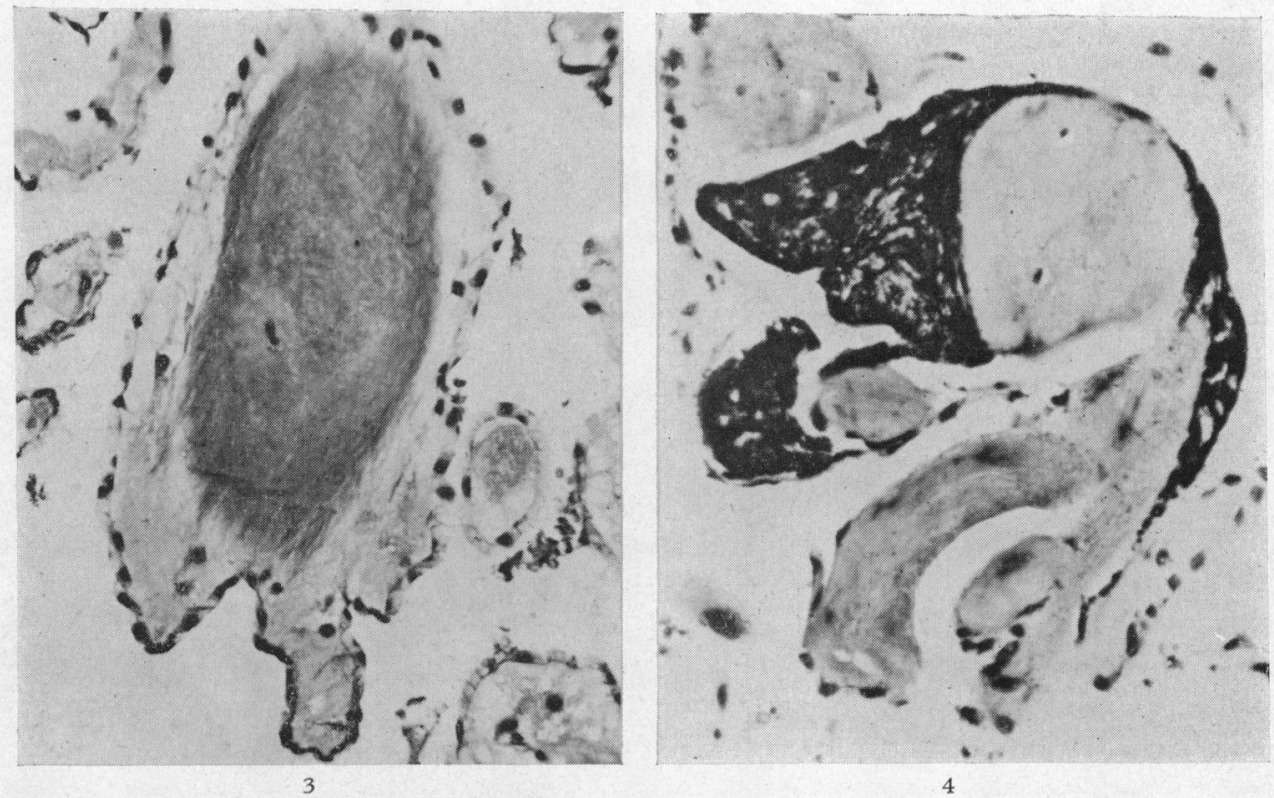

FIG. 3.-Transverse section of a papilla showing the central core, the surrounding sheath, and the covering endothelial cells. (Hæmatoxylin and van Gieson. $\quad \times 215$.)

FIG. 4. - Transverse section of a papilla showing the deposition of fibrin (shown as black) around the central core. (Phosphotungstic acid hæmatoxylin. $\times 250$.) 


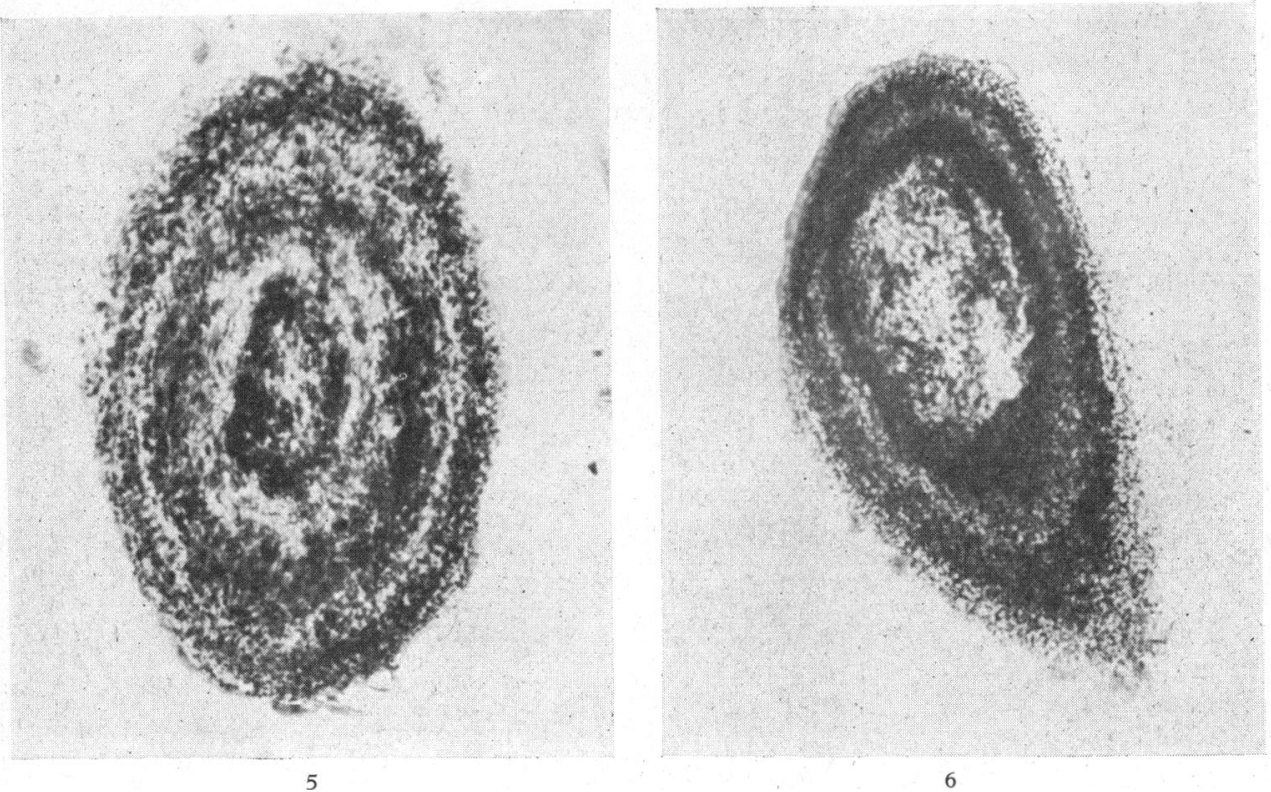

FIG. 5.-Transverse section of a papilla showing the particulate elastic tissue arranged in laminar form. (Lawson modification of Weigert-Sheridan stain. $\quad \times 450$.)

Fig. 6.-Transverse section of another papilla showing the particulate elastic tissue arranged in laminar form. (Weigert-Sheridan. $\times 250$.)

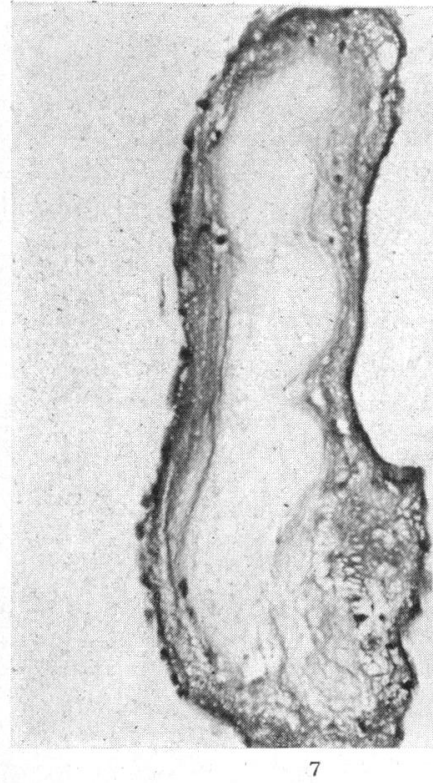

FIG. 7.-Transverse section of a papilla showing dense accumulation of metachromatic material in the sheath. (Toluidine blue. $\times 135$.)

FIG. 8. - Transverse section of the same papilla. The metachromasia has been prevented by previous treatment of the section with hyaluronidase. (Toluidine blue after incubation with testicular hyaluronidase.

7

高

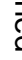

\section{ह}

$\overrightarrow{0}$

N

\%

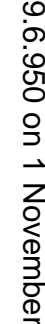


Interpretation of Histochemistry. The core appeared to be composed of collagen and elastin, though it is possible that some of the material taking up the stain for elastin was in fact old fibrous tissue. Closely applied to the periphery of the core were deposits of fibrin. The sheath contained acid mucopolysaccharides and, in particular, hyaluronic acid.

TABLE

STAINING REACTION OF CORE AND SHEATH OF PAPILLE

\begin{tabular}{l|c|c}
\hline \multicolumn{1}{c|}{ Stain } & Core & Sheath \\
\hline \begin{tabular}{l|c} 
Hæmatoxylin and eosin \\
Van Gieson
\end{tabular} & $\begin{array}{c}\text { Eosinophilic } \\
\text { Pink }\end{array}$ & $\begin{array}{c}\text { Basophilic } \\
\text { Yellow to } \\
\text { faint pink }\end{array}$ \\
\begin{tabular}{l|c} 
Weigert-Sheridan \\
Perls
\end{tabular} & + & - \\
Periodic acid-Schiff & - & Faint \\
Mucicarmine & - & - \\
Alcian blue & - & + \\
Hale's dialysed iron & - & + \\
Toluidine blue & - & - \\
Toluidine blue after extraction & - & + \\
wcith testicular hyaluronidase & + & + \\
Martius scarlet blue & + & + \\
Phosphotungstic acid hæmatoxylin & - & + \\
\hline
\end{tabular}

\section{Discussion}

The gross and microscopic appearances of the intraventricular polyps described here are identical with those of "papillary tumours of heart valves" as described by many previous authors. For a complete bibliography of such case reports the reader is referred to the paper by Pomerance (1961). Usually such lesions occur on the ventricular surface of the semilunar valves or on the atrial surface of the atrio-ventricular valves (Raeburn, 1953). The present case appears to be unique in that the polyps had grown from the endocardial surface of the left ventricle into its cavity.

The nature of these "tumours" is controversial. Many pathologists have regarded them as true neoplasms and as early as 1929 Bohrod reported that they had been described as myxoma, fibroma, fibroangio-myxoma, and hæmangio-elasto-myxoma, depending on the predominant tissue seen in the particular specimen reported. To this already imposing list he added the term hæmangiofibroma. Raeburn (1953) called these papilliferous masses hamartomas, suggesting that this term should be qualified in a particular case by prefixing a description of the predominant tissue present. $\mathrm{He}$ believed them to have a limited capacity for growth, which was not significantly greater than that of the surrounding normal tissues.

However, according to Hertzog (1936), as long ago as 1871-2 Curtis had doubted the neoplastic nature of such lesions and considered it more likely that they were inflammatory in origin, as there was often evidence of preceding endocarditis in the affected valves. Koechlin (1908) went even further in suggesting that such polyps were nothing more than unusually large excrescences of Lambl (1856). Such excrescences are almost ubiquitous on human valves after infancy and are formed by the organization of small deposits of fibrin on sites of endothelial damage (Magarey, 1949). Lambl's excrescences are covered by a single layer of endothelium, and are usually avascular with an acellular fibrous stroma with admixed elastic fibrils. Pomerance (1961) was impressed by the similarity of the histological appearances of these excrescences and the larger more complex "papillary tumours of heart valves", and she thought it likely that these polyps originated in and grew from the close approximation of Lambl's excrescences. She observed that intermediate forms between excrescence and "papillary cardiac tumour" existed, differing from the two lesions only in the numbers of processes present and in the thickness of the pedicle. An important point in her argument was the demonstration of fibrin around the papillæ suggesting progressive growth of them by the deposition and organization of fibrin. The results of our histological studies are consistent with her view. We have confirmed the presence of fibrin around the central cores of the papillae (Fig. 4). The lamination of particulate tissue taking up the stain for elastic in the cores (Fig. 5 and 6) also seems to be consistent with the concept that these polyps grow by successive phases of organization of such deposited fibrin. If one accepts that "papillary tumours" are derived from Lambl's excrescence and grow by deposition of fibrin on them, one would anticipate finding them especially in patients prone to the formation of thrombi in the cardiac chambers. This is true of the patient described here who had chronic rheumatic heart disease which had necessitated two valvotomies. Three of the six cases of "papillary tumour of heart" described by Pomerance (1961) had rheumatic mitral stenosis.

The papillary nature of these polyps (Fig. 1 and 2) may to some extent be determined by their exposure to the hæmodynamic stresses of the movement of blood in the left ventricle or on cardiac valves. It is of interest to compare their form with the smooth ovoid appearance of the majority of atrial myxomas which grow in the relatively calm fluid environment of the atria and are not subjected to such hæmodynamic stimuli.

It is worthy of comment that the histological appearances and the histochemistry of the sheaths of the papillæ of papillary tumours of heart valves are identical with those of the mucinous stroma of the cardiac myxoma. Both contain copious 
amounts of an acid mucopolysaccharide which appears to be hyaluronic acid, for in both the characteristic metachromasia with toluidine blue is prevented by previous treatment with testicular hyaluronidase (Fig. 7 and 8) (Raeburn, 1953; Heath, Best, and Davis, 1961; Heath and Mackinnon, 1964).

It is commonly believed that "papillary tumours of heart valves" are of no clinical importance (Bohrod, 1929; Pomerance, 1961). However, if they arise near the ostium of a coronary artery they may give rise to severe anginal pain (Heath et al., 1961).

\section{Summary}

A woman of 39 years was subjected to an emergency valvotomy for mitral stenosis. At necropsy she was found to have polyps on the endocardial surface of the left ventricle identical in structure with so-called "papillary tumours of heart valves". The results of histochemical studies are consistent with the view that these "tumours" may be giant Lambl's excrescences.
We wish to thank Mr. J. Leigh Collis for allowing us to report this case.

\section{References}

Bohrod, M. G. (1929). Multiple hemangiofibroma of the pulmonary valve. Arch. Path., 8, 68.

Curtis, B. (1871-2). Note sur une tumeur de la valvule mitrale. Arch. Physiol. norm. path., 4, 262.

Heath, D., Best, P. V., and Davis, B. T. (1961). Papilliferous tumours of the heart valves. Brit. Heart f., 23, 20.

-, and Mackinnon, J. (1964). Pulmonary hypertension due to myxoma of the right atrium. Amer. Heart f., 68, 227.

Hertzog, A. J. (1936). Papillary fibroma of cardiac valve. Arch. Path., 22, 222.

Koechlin, E. (1908). Uber primäre Tumoren und papillomatöse Exkreszenzen der Herzklappen. Frankfurt. $Z$. Path., 2, 295.

Lambl, V. A. (1856). Papillare Excrescenzen an der Semilunar-Klappe der Aorta. Wien. med. Wschr., 6, 244.

Magarey, F. R. (1949). On the mode of formation of Lambl's excrescences and their relation to chronic thickening of the mitral valve. F. Path. Bact., 61, 203.

Pomerance, A. (1961). Papillary "tumours" of the heart valves. F. Path. Bact., 81, 135.

Raeburn, C. (1953). Papillary fibro-elastic hamartomas of the heart valves. F. Path. Bact., 65, 371. 